\title{
Challenges to the state policy towards migration processes in Poland
}

\begin{abstract}
In quantitative dimension, Poland is a significant émigré country in which the scale of external outflow has been maintained at the level of about 2 million people for many years. In the light of (Central Statistical Office) data in 2016, 2 million 515 thousand Poles were abroad temporarily for a period of more than 3 months.

An important task of migration policy is therefore to minimise the negative effects of mass emigration and to maximise the benefits resulting from this process. At the same time, in the decade after 2010, the volume of foreigners coming to Poland increased significantly and it should be expected that, as the socio-economic attractiveness of the country has grown, this group would be increasing as well. According to the Ministry of Family, Labour and Social Policy (Ministerstwo Rodziny, Pracy i Polityki Społecznej) data, 235626 work permits were issued in 2017, including 192547 to Ukrainian citizens (ca. 82\%). To compare, in the same year, the district employment offices (Powiatowy Urzad Pracy) registered 1824464 declarations of intention to work to foreigners, including 1714891 towards the citizens of Ukraine (94\%). The discussion on the nature of immigration policy is therefore unavoidable. The growing inflow of foreigners is gaining a special demographic, social and political significance in the context of unfavourable forecast of population changes in Poland. It also has an important regional dimension. From this perspective, foreigners will be needed on the Polish labour market to alleviate already existing and projected shortages of labour resources.

An important challenge is to develop a strategy for the integration of social, economic and cultural foreigners into the Polish society. Consequently, the persistent mass emigration, growing immigration, unflagging migration potential and, more expected than real, the return of Poles from emigration are a great challenge for the Polish economy and society as well as for regions. This multidimensional nature of foreign migration in Poland makes the emergence of migration policy system, corresponding to internal and external conditions, a necessity.

The postulate of the formulation of the foundations of a migration policy appeared in Poland at the beginning of the 1990s, but until now a coherent system of this policy has failed to develop as a complementary element of the socio-economic policy of the country.
\end{abstract}

Keywords: Poland, migration processes, migration Policy, labour market. 


\section{Introduction}

Poland is an important European emigration country where for many years the scale of emigration has remained at the same level of around 2 million people. As data from GUS (Central Statistical Office) show, in 2016, 2 million 515 thousand Poles were temporarily staying abroad for the period of over 3 months (Informacja o rozmiarach i kierunkach... 2017: 2). At the same time, the number of foreigners coming to Poland has significantly increased in recent years. Data from the MRPiPS (Ministry of Family, Labour and Social Policy) show that in 2017, 235626 work permits were issued, including 192547 permits for Ukrainian citizens (81.7\%). In the same year, 1824464 state-ments of intention to entrust work to a foreigner were registered in district labour offices, including 1714891 for Ukrainian citizens (94\%) (Liczba i struktura oświadczeń... 2017).

In this situation, the large scale of emigration, especially dynamically growing immigration, is becoming a real challenge for the Polish economy and society. The creation of the system of migration policy that would become a complementary element of socio-economic policy of the state is one of them ${ }^{1}$. An important task of this policy should be to minimise the negative effects of mass migration and to maximise the benefits resulting from this process, especially to develop the strategy of social, economic and cultural integration of foreigners into the Polish society.

\section{Migration policy in Poland}

The postulate of formulation of the foundations of a migration policy first appeared in Poland at the beginning of the 1990s as a consequence of the processes of transformation and democratisation, as well as progressive liberalisation of the principles of crossing borders and the growing scale of migration movements. However, so far neither a coherent system of migration policy, nor the final shape of the migration doctrine reflecting Polish national interest and state philosophy on the basis of which the principles of this policy could be formulated have been developed. However, accession to the EU and the necessity to adopt the Community law in this area caused significant changes in the migration policy of Poland. This was because it was necessary to adapt the national law to the principles of the Schengen Agreement and to introduce its provisions in the sphere of border control, refugee policy, visa system and migration policy (Balicki, Stalker 2006: 351). At the same time, Poland was obliged to prepare the main principles of the national migration policy, embedded in the framework of European migration policy and subordinated to the principle of subsidiarity ${ }^{2}$.

${ }^{1}$ Compare: M. Okólski (2012: 23-44).

${ }^{2}$ Wyzwania dla narodowej polityki migracyjnej... (2004: 39). 
The act regulating the entry and stay of the European Union citizens and their families on the territory of Poland was adopted on the accession day. It was a part of acquis and constituted mandatory and basic legal solutions promoting freedom of movement of the citizens within the EU. Furthermore, on the basis of experiences of Western European countries, the Act on Foreigners was adopted in 1997. It was very restrictive and limiting to legal migration channels (Górny et al. 2010: 8; Balicki, Wells 2006). However, in subsequent years it has been changed and amended several times. At the same time, the new Constitution of the Republic of Poland of 1997 guaranteed foreigners the right to seek asylum in Poland. There were also debates concerning the draft of the Polish Charter Act which came into force in 2008 and the Repatriation Act passed in 2000.

The Act on Foreigners regulates the principles and conditions for foreigners' entry into, transit through, stay and exit from Poland, as well as the conditions for granting protection to foreigners. Clearly increasing liberalisation of foreigners' access to the Polish labour market has been observed in recent years.

Further facilitations in the employment of migrants involved the reduction of costs of issuing work permits, abolishing the institution of promise of issuing work permit, acceleration of the so-called "labour market test" or the possibility of its abandonment (Matkowska 2013: 77-92). The latest, and significant, amendment to the Act on Foreigners occurred in 2018. It introduced several changes in the regulations that should cause streamlining of the proceedings and partial change in the requirements that concern granting individual residence permits. For example, a formal requirement to enclose, with the application, the so-called poviat governor's information on the lack of possibility to meet employer's staffing needs on the basis of registers of the unemployed and those seeking employment or on the negative result of recruitment process organised for the employer ${ }^{3}$ was abolished. The above change concerns the applications to grant temporary residence permits and work permits, as well as applications for temporary residence permit to perform work demanding high qualifications.

In 2009, Inter-ministerial Committee for Migration started the work on the development of the principles of a migration policy that was adopted in 2012 in the form of a document entitled: Polityka migracyjna Polski - stan obecny $i$ postulowane dziatania (Migration policy of Poland - current situation and postulated actions $)^{4}$. In addition to the summary of the principles of the migration policy of the state, the document included the directions and recommended actions in this area. At the time, the document was presumed to be the interpretation of the operating migration strategy of the state. In 2014, the plan of its implementation was adopted. It included a catalogue of actions and proposals for solutions aimed

\footnotetext{
${ }^{3}$ Urząd do Spraw Cudzoziemców, https://udsc.gov.pl/nowelizacja-ustawy-o-cudzoziemcach/

${ }^{4}$ Polityka migracyjna Polski... (2012).
} 
at achieving the of adopted policies along with an indication of the entities responsible for their implementation as well as a determination of the costs of implemented instruments and sources of financing for planned expenditures ${ }^{5}$. Concurrently with the work on Migration policy of Poland..., development was started on the next document entitled Polish policy of foreigners' integration - principles and guidelines. Its draft was approved in 2014, yet it was not adopted and did not perform a significant role in the creation of the integration policy (Wach 2018: 347-369; Kubiciel-Lodzińska, Solga 2017: 797-810).

The so-called migration crisis and the mass influx of migrants into Europe started in 2015 caused a spike in the interest in the issues of migration, while at the same time resulting in significant politicisation of this problem (Lesińska, Duszczyk 2018: 251-264; Bonifazi 2008: 107-128; Heffner, Solga 2008: 49-62). However, increased interest in migration policy has not brought considerable changes in the formation of the system of migration policy of Poland. On the contrary, some of the previous strategic documents, including Migration policy of Poland..., were withdrawn in 2016. In 2018, very general priorities of the new migration policy were described in the document entitled Priorytety spoteczno-gospodarcze polityki migracyjnej (Socio-economic priorities of migration policy).

\section{Most important challenges in the sphere of migration policy}

From the perspective of the present migration situation in Poland, as well as from the point of view of the very definition of migration policy, which frames it as a system comprising the actions of the state towards its own diaspora and towards foreigners residing in its territory, Poland faces serious challenges. Certainly, Poland as a democratic country has limited possibilities of real impact on individual decisions that concern remaining in the country, departure or return (Chałupczak et al. 2014: 307-331). However, an appropriate system of institutional support addressed to immigrants and people returning from abroad, as well as information policy aimed at those making decisions about emigration can be created. At the same time, public institutions have a decisive impact on these socio-economic spheres that directly determine decisions concerning emigration related to stable employment, remuneration, quality of the social security system, and the level of education.

The outflow of young and educated Poles justifies the need to include in migration policy the actions targeted at people returning from abroad. Facilitation of returns, if they are permanent and consistent, can become an important factor allowing for the utilisation of re-emigrant's potential (Heffner, Solga 2009: 137-146). Such system of support may include assistance in quick implementation

\footnotetext{
${ }^{5}$ Plan wdrażania dla dokumentu ,Polityka migracyjna Polski-stan obecny i postulowane działania" (2013).
} 
of returnee's investment plans or actions aimed at overcoming socio-occupational exclusion (e.g. trainings organised by employment agencies, professional career advisory services or psychological workshops).

Due to a dynamic increase in the inflow of foreigners, the policy of social, economic and cultural integration is facing serious challenges (Szymańska-Zybertowicz 2011). In the context of foreigners' influx to Poland, forecasted unfavourable demographic changes also need to be taken into consideration. Considerable population loss, deep changes in the population structure by age and population ageing over the next few decades will be serious problems for the economy and society. Consequently, immigrants will be needed on the Polish labour market to alleviate the anticipated shortages and to become the source of acquisition of new workers. The purpose of immigration policy in this context would be the flexible replenishment of shortages emerging on the Polish labour market, both in seasonal and long term perspectives, and the prevention of foreign nationals' inflow being an alternative to the employment of Polish or other EU nationals (Szylko-Skoczny, Duszczyk 2008; Szylko-Skoczny 2013: 80-92).

In this approach, migration policy should be a comprehensive system, comprising both the issues concerning immigration as well as migration, re-emigration and even potential emigration. It should also be integrated with other public policies (Solga 2015: 133-147).

\section{Instruments of migration policy - selected issues}

The identification of instruments of socio-economic policy that enable effective control of migration processes and the formation of an institutional system aimed at supporting migrants are extremely important in creating a migration policy. Traditional factors such as good law, stable economy, guarantee of work and its high quality, well-developed technological infrastructure, properly functioning system of social security are fundamental in this policy. They will always be a magnet for people who consider leaving the country, returning to the country or migration for economic reasons. Among them, the instruments strengthening the labour market are particularly important. Active approach in the sphere of employment policy may involve training programmes for people returning from abroad and offering them assistance in finding their place on the labour market, support in re-training, programmes of acclimatisation and assistance in starting their own business activity. In the case of immigrants, this includes significant simplifications while starting work, the possibility to establish companies and the perspective of migration for settlement (Lesińska, Stefańska 2010; Kubiciel-Lodzińska, Ruszczak 2018: 425-440). This means that, as already indicated, the instruments of a migration policy should be an element of a coherent and coordinated system and apply to all migration groups - emigrants residing abroad, 
people returning from abroad, immigrants, and potential emigrants (Solga 2013: 325-330; Heffner, Solga 2017: 11-26). In the case of expatriates, actions aimed at the maintenance of migrants' bond with their country/region of origin, for example through portals informing about the current situation in the country, about the housing situation or the situation on the labour market and the possibilities to establish their own company seem the most important. Measures promoting changes occurring in the country/region or even organisation of meetings with representatives of specific institutions, e.g. local governments, entrepreneurs, labour market experts in the places of largest Polish community concentration can also bring positive results (Van Mol, de Valk 2016). Finally, involvement of emigrants in socio-cultural life of the region of origin (e.g. through local associations) will support maintenance of bonds with the country of origin.

Similarly, in the case of people who are planning to return or have already returned from abroad, reliable information about the country/region, especially the opportunities related to employment are the most important. Institutional support concerning official issues related to return, career guidance and training offers allowing for raising qualifications or re-training are the elements of the catalogue of instruments targeted at re-emigrants. Certainly, specific psychological tools should be developed and applied in frequently difficult processes of re-integration of returnees. Special attention should be focused on people who graduated from universities abroad. They should be offered the possibility to write their $\mathrm{Ph} . \mathrm{D}$. dissertation or encouraged to implement innovative research projects in scientific institutions.

In the case of immigrants, this is about improvement of the recruitment mechanisms (institutions and procedures) and advisory services related to official matters concerning arrival, work permit, extension of stay, residency registration, change of address, etc. Development of integration strategy is a big challenge facing Polish society. This task is broad and can concern many areas including economic, legal, civic, political, social, cultural, religious, identity as well as spatial matters (Podgórska, Trevena 2018: 265-282). Educational actions addressed at employers hiring foreigners, in the field of culture of the country of workers' origin and development of the skill of prevention of conflicts between Polish workers and foreigners are also its important elements.

Last but not least, activities aimed at potential emigrants are also vital so that their decisions to leave are taken rationally. Therefore, information about the possibility to find employment abroad and social security systems in individual countries is also important. Career guidance comprising analysis of career paths that includes (or not) migration abroad ought to be developed on the basis of individual capabilities and occupational plans, assistance in selection of the best direction of migration and occupational activity as well as raising awareness of non-work-related consequences of the decision about emigration. 


\section{Conclusions}

Discussion on the issues of migration policy in Poland is important for at least three reasons. Firstly, because Poland is still a significant emigration country in which the scale of migration is considerable. At the same time, substantial transformations occur in the demographic structure of migrants and their directions of migration, and consequences of migration are still felt in both demographic and economic matters. Due to this, minimisation of negative effects of mass migration and maximisation of benefits resulting from this process are an important objective of the migration policy that is being shaped.

Dynamically growing number of foreigners coming to Poland is another reason for the discussion on the shape of migration policy. Therefore, discussion on the nature of immigration policy, especially integration policy, is becoming essential and inevitable.

Finally, the rising influx of foreigners and still considerable scale of emigration from Poland finally gain special importance in the context of forecasted demographic changes. Considerable population loss, dramatic changes in the structure of population by age and population ageing in the perspective of the next few decades are becoming a serious challenge facing Polish society. Migration policy can also represent an important tool that supports solving problems that result from demographic changes. It is complementary towards other public policies, especially pro-family and labour market policies.

However, it is important that migration policy should become a tool of socio-economic development that controls the processes of changes on labour market and in its social environment. Apart from activities targeted at economic development and improvement of living conditions that are essential from the point of view of population mobility, many further instruments of socio-economic policy aimed at migrants and consequently enabling efficient use of the opportunities and balancing the loss that is the result of migration should be identified and then used. The system created in this way would be aimed at simultaneous application of diverse activities towards each of migration groups in order to prepare people for departure, return and migration, as well as at implementation of tools through which decisions about departure, return and possibly also immigration would be conscious and rational.

A state migration policy should take into consideration the needs of regions in this sphere. This means that solutions developed within a migration policy at the central level are not sufficient; they should be complemented by the instruments for local governments, specific legal and financial principles and even the entities executing tasks in the sphere of broadly perceived migration issues. 


\section{References}

Balicki J., Stalker P., 2006, Polityka imigracyjna i azylowa, Wydawnictwo Uniwersytetu Kardynała St. Wyszyńskiego, Warszawa.

Balicki J., Wells A., 2006, Asylum Seekers'Policyv Integration Policy. Case Study of Kosovan Families in the East End of London (2003-2005), Trafford Publishing, Oxford UK.

Bonifazi C., 2008, Evolution of regional patterns of international migration in Europe, [in:] Bonifazi C., Okólski M., Schoorl J., Simon P. (eds.), International migration in Europe: New trends and new methods of analysis, IMISCOE Research Series, Amsterdam University Press, Amsterdam.

Chałupczak H., Firlit-Fesnak G., Lesińska M., Solga B., 2014, Polityka migracyjna Polski wobec najnowszej emigracji Polaków po 2004 roku, [in:] Lesińska M., Okólski M., Slany K., Solga B. (eds.), Dekada członkostwa Polski w UE. Społeczne skutki emigracji Polaków po 2004 roku, Komitet Badań nad Migracjami PAN, Ośrodek Badań nad Migracjami, Uniwersytet Warszawski, Warszawa.

Górny A., Grabowska-Lusińska I., Lesińska M., Okólski M. (eds.), 2010, Transformacja nieoczywista. Polska jako kraj imigracji, Uniwersytet Warszawski, Warszawa.

Heffner K., Solga B., 2008, Foreign migration of Poles in scientific research on the turn of century, "Bulletin of Geography. Socio-Economic Series", 10: 49-62, Toruń.

Heffner K., Solga B., 2009, Evolution of social, cultural and economic processes in border regions (using the example of Opole Silesia), [in:] Sobczyński M. (ed.), Historical Regions Divided by the Borders. General Problems and Regional Issue, University of Łódź, Department of Political Geography and Regional Studies, Governmental Research Institute Silesian Institute, Silesian Institute Society, Seria: "Region and Regionalism", 9(1): 137-146, Łódź-Opole.

Heffner K., Solga B., 2017, International migration and population decline in the regions with national minorities in Poland on the example of Opolskie Voivodeship, [in:] Heffner K., Solga B. (eds.), Borderlands of nations, Nations of Borderlands. National, ethnic and religious minorities in the Polish space - selected issues, University of Łódź, Department of Political Geography and Regional Studies, Governmental Research Institute Silesian Institute, Silesian Institute Society, Seria: "Region and Regionalism", 13(2): 11-26, Łódź-Opole.

Informacja o rozmiarach i kierunkach czasowej emigracji z Polski w latach 2004-2016, 2017, Główny Urząd Statystyczny, Warszawa.

Kubiciel-Lodzińska S., Ruszczak B., 2018, The attractiveness of Poland for economic migrants. Assessment by employers: results of empirical studies, "Olsztyn Economic Journal”, 13: 425-440, Uniwersytet Warmińsko-Mazurski w Olsztynie.

Kubiciel-Lodzińska S., Solga B., 2017, Poland: immigration instead of emigration. Transformation of the mobility model, [in:] The $30^{\text {th }}$ International Business Information Management (IBIMA) Conference, 8-9 November 2017, Madrid, Spain: 797-810.

Lesińska M., Duszczyk M., 2018, Polityka migracyjna, [in:] Lesińska M., Okólski M. (eds.), 25 wykładów o migracjach, Wydawnictwo Naukowe Scholar, Warszawa. 
Lesińska M., Stefańska R., 2010, Polityka migracyjna oraz rozwiazania dotyczace dostępu cudzoziemców do rynku pracy. Raport o rozwiazaniach przyjętych $w$ wybranych państwach Unii Europejskiej, Uniwersytet Warszawski, Warszawa.

Liczba i struktura oświadczeń zarejestrowanych przez powiatowe urzędy pracy $w$ roku 2017, Ministerstwo Rodziny, Pracy i Polityki Społecznej, http://psz.praca.gov.pl/ web/urzad-pracy/-/8180205-rejestracja-oswiadczen-pracodawcow-o-zamiarzepowierzenia-pracy-cudzoziemcowi

Matkowska M., 2013, Polska polityka migracyjna - zarys problemu, "Studia i Prace WNEiZ", 33(1).

Okólski M., 2012, Transition from emigration to immigration: Is it the destiny of modern European societies?, [in:] Okólski M. (ed.), European immigrations: Trends, structures and policy implications, IMISCOE Research Series, Amsterdam University Press, Amsterdam: 23-44.

Plan wdrażania dla dokumentu "Polityka migracyjna Polski - stan obecny i postulowane działania”, 2013, Departament Polityki Migracyjnej MSW, Warszawa.

Podgórska K., Trevena P., 2018, Polityka integracyjna: teoria i praktyka, [in:] Lesińska M., Okólski M. (eds.), 25 wykładów o migracjach, Wydawnictwo Naukowe Scholar, Warszawa.

Polityka migracyjna Polski - stan obecny i postulowane działania, 2012, Departament Polityki Migracyjnej MSW, Warszawa.

Solga B., 2013, Miejsce $i$ znaczenie migracji zagranicznych $w$ rozwoju regionalnym, Politechnika Opolska, Opole.

Solga B., 2015, Polityka migracyjna jako element polskiej polityki społecznej, "Wieś i Rolnictwo", 3(168): 133-145.

Szylko-Skoczny M., 2013, Labour Market Policy, [in:] Facing the challenges. Social policy in Poland after 1990, Poznań University of Economics Press, Poznań: 80-92.

Szylko-Skoczny M., Duszczyk M., 2008, Polish immigration policy - opportunities and challenges for the labour market, http://www.ips.uw.edu.pl/pliki/badania/politimigrac rynekpracy2010/immigr_policy_en.pdf

Szymańska-Zybertowicz K., 2011, Nieobecne wyzwanie? Integracja jako zadanie polityki społecznej wobec cudzoziemców w Polsce po 1989 r., Uniwersytet Mikołaja Kopernika, Toruń.

Urząd do Spraw Cudzoziemców, https://udsc.gov.pl/nowelizacja-ustawy-o-cudzoziemcach/

Van Mol C., de Valk H., 2016, Migration and Immigrants in Europe: A Historical and Demographic Perspective, [in:] Garcés-Mascareñas B., Penninx R. (eds.), Integration Processes and Policies in Europe, IMISCOE Research Series, Springer, Cham.

Wach D., 2018, Ewolucja polskiej polityki integracji cudzoziemców po 1989 r., [in:] Chałupczak H., Lesińska M., Pogorzała E., Browarek T. (eds.), Polityka migracyjna w obliczu współczesnych wyzwań. Teoria i praktyka, Komitet Badań nad Migracjami PAN, Uniwersytet Marii Curie-Skłodowskiej, Uniwersytet Warszawski, Lublin. 
Wyzwania dla narodowej polityki migracyjnej w kontekście UE. Doświadczenia Polski i Niemiec. Podsumowanie seminarium zorganizowanego przez Centrum Stosunków Międzynarodowych w Warszawie, 11.09.2003, 2004, M. Mazur-Rafał (elabor.), Centrum Stosunków Międzynarodowych, Warszawa.

\section{Wyzwania dla polityki państwa wobec procesów migracyjnych w Polsce}

Zarys treści: Ze względu na wielkość, Polska jest znaczącym krajem emigracyjnym, w którym od wielu lat utrzymuje się skala odpływu zewnętrznego na poziomie około 2 mln ludzi. W świetle danych Głównego Urzędu Statystycznego, w 2016 r. 2 mln 515 tys. Polaków przebywało tymczasowo za granicą przez okres dłuższy niż 3 miesiące.

Ważnym zadaniem polityki migracyjnej jest zatem zminimalizowanie negatywnych skutków masowej emigracji i maksymalizacja korzyści wynikających z tego procesu. Jednocześnie w dekadzie po 2010 roku znacznie wzrosła liczba cudzoziemców przybywających do Polski i należy oczekiwać, że w miarę wzrostu atrakcyjności społeczno-ekonomicznej kraju grupa ta będzie rosła. Według danych Ministerstwa Rodziny, Pracy i Polityki Społecznej w 2017 roku wydano 235626 zezwoleń na pracę, w tym 192547 dla obywateli Ukrainy (ok. 82\%). Równolegle w tym samym roku powiatowe urzędy pracy zarejestrowały 1824464 deklaracji zamiaru podjęcia pracy przez cudzoziemców, w tym 1714891 przez obywateli Ukrainy (94\%). Dyskusja na temat charakteru polityki imigracyjnej jest zatem nieunikniona. Rosnący napływ cudzoziemców nabiera szczególnego znaczenia demograficznego, społecznego i politycznego w kontekście niekorzystnych prognozowanych zmian populacji w Polsce, ma także istotny wymiar regionalny. $\mathrm{Z}$ tej perspektywy cudzoziemcy będą potrzebni na polskim rynku pracy, aby złagodzić już istniejące i prognozowane niedobory zasobów pracy.

Ważnym wyzwaniem jest opracowanie kompleksowej strategii integracji społecznej, gospodarczej i kulturalnej cudzoziemców ze społeczeństwem polskim. W związku z tym utrzymująca się masowa emigracja, rosnąca imigracja, niesłabnący potencjał migracyjny oraz - bardziej oczekiwany, niż rzeczywisty - powrót Polaków z emigracji stanowią wielkie wyzwanie dla polskiej gospodarki i społeczeństwa, a także dla regionów. Ten wielowymiarowy charakter migracji zagranicznych w Polsce powoduje, że pojawienie się systemowej polityki migracyjnej, odpowiadającej warunkom wewnętrznym i zewnętrznym, staje się koniecznością.

Postulat sformułowania założeń polityki migracyjnej pojawił się w Polsce na początku lat 90 ., ale do tej pory spójny system tej polityki nie rozwinął się jako uzupełniający element polityki społeczno-gospodarczej kraju.

Słowa kluczowe: Polska, procesy migracyjne, polityka migracyjna, rynek pracy.

Krystian Heffner

University of Economics in Katowice, Poland

Department of Spatial and Environmental Economics

e-mail: krystian.heffner@ue.katowice.pl

Brygida Solga

Silesian Institute, Opole, Poland

e-mail: brygidasol@wp.pl 